\title{
20. Yüzyıl Batı Ve İslam Düşüncesinde Sosyal Adalet Yaklaşımı
}

\author{
Osman Erdal ŞAHIN ${ }^{I}$
}

\section{Özet}

Sosyal adalet, toplumsal hakların bütün bireylerce yaşanabilir olduğu kapsamlı bir adalet olarak tanımlanmaktadır. Toplumu oluşturan bireylerin belirli haklar üzerindeki ilişkilerini açıklayan sosyal adalet, Batı ve İslam düşüncesinde farklı yorumlanmaktadır. Batı düşüncesinde ekonomi politiğin içerisinde gelişme gösteren sosyal adalet, birçok dengesizliğin giderilmesinde bir araç olmuştur. Modern Batı düşüncesinde sosyal adalet, güzel bir yaşam için gerekli bir araç iken İslam düşüncesinde doğru, erdemli ve ahlaki (faziletli) bir toplumun tesisi için önemlidir. Bu çalışmanın ilk kısmında Batı düşüncesinde sosyal adalet yaklaşımları ele alınırken önde gelen bazı sosyal adalet teorisyenlerinin yaklaşımları incelenmiştir. Sosyal adaleti daha çok iktisadi eşitsizlikler temelinde ele alan Batı düşüncesi karşısında son dönemin bazı İslami düşünürlerin yaklaşımlarına çalışmanın ikinci kısmında yer verilmiştir. Bu İslami düşünürlerin, sosyal adaletin önemine dair nasıl bir anlayış ortaya koydukları üzerinde durulmuştur. Bu çalışmanın amacı Batı ve İslam düşünce sisteminde sosyal adaletin önemini niteliksel farklarla birlikte değerlendirmektir. Her iki düşünce sisteminin kendi iç dinamik ve toplumsal yapılarında var olan farklılıkları çağdaş form ve söylemler içerisinde değerlendirmeye çalışmaktadır. Bunun için çalışmada her iki ekolün çağdaş düşünürlerinden Rawls ve Miller, Kutup, Mevdudi ve Nursi’nin sosyal adalete yönelik yaklaşımları incelenmiştir.

Anahtar Kelimeler: Sosyal Adalet, Eşitlik, Miller, Rawls, Kutub, Mevdudi, Nursi

\section{Approaches To Social Justice: The Western And Islamic Thought In The 20th Century}

\begin{abstract}
Social justice is defined as a comprehensive understanding of justice in which every individual fulfils their social rights. Social justice, which explains the relations of the individuals who make up the society on certain rights, is interpreted differently in Western and Islamic thought. In the Western thought, social justice is built on the political economy, and it is used as a tool to diminish imbalances. In modern Western thought, social justice is a necessary tool for good life while it is necessary for the establishment of a right, virtuous and moral society in Islamic thought. The first part of this study analyses the approaches on social justice in Western thought, in particular some contemporary social justice theorists are examined. In the second part, some Islamic thinkers are taken into consideration as an alternative to the Western understanding of social justice in terms of economic inequalities. It is emphasized how these Islamic thinkers have an understanding of the importance of social justice. The aim of this study is to evaluate the importance of social justice in the twentieth century Western and Islamic thought systems with qualitative differences, and to evaluate the concept of social justice within the contemporary discourses and within the differences in the internal dynamics and social structures of both thought systems. Therefore, in this study the approaches of Rawls and Miller, Qutb, Mawdudi and Nursi to the social justice are examined as the modern representatives of the two school of thought.
\end{abstract}

Keywords: Social Justice, Equality, Miller, Rawls, Qutb, Mawdudi, Nursi.

${ }^{1}$ Arş. Gör., Uludağ Üniversitesi, Siyaset Bilimi ve Kamu Yönetimi Bölümü, osmanerdalsahin@gmail.com 


\section{Giriş}

Sosyal adalet, toplum içerisindeki ekonomik ve sosyal eşitsizliklerin giderilmesi, ekonomik olarak güçsüz durumda bulunan insanların diğer güçlü insanlara veya kesimlere karşı korunması olarak tanımlanır. Özellikle bireylerin, bulundukları toplumda insan haysiyetine yaraşır bir şekilde asgari hayat standardına kavuşmalarını sağlayan ve hem bireyin hem de toplumun haklarını gözeten düzenlemeler olarak da tarif edilir. Toplumu meydana getiren bireylerin ortak çalışması ile oluşturulan faydanın dağıtımı ve toplumsal adaletsizliklerin giderilmesi sosyal adaletin sağlanmasına bağlıdır. Bu bağlamda toplum için maddi yaşanabilir çevreyi oluşturan hava, su gibi hayati faktörlerin önemi gibi sosyal adaletin varlığı da toplumun huzur ve sürekliliği açısından önem arz etmektedir.

Sosyal adalet, İslam düşüncesinde en esaslı bir şekilde asırlardır mevcut olduğu düşünülürken Batı düşünce sisteminde belirgin olarak son yüzyıllarda artan toplumsal eşitsizlikler ve düzensizliklerle ortaya çıkmıştır. Bu bağlamda modern Batı düşüncesi, sosyal dengesizliklerin ve adaletsizliklerin giderilmesi için farklı yaklaşımlar ve teoriler üretmiştir. Batı düşüncesinin temel yaklaşımında insanı merkeze alan bir adalet anlayışı benimsenmiştir. Bunun ile değişen dünya düzeninde toplumsal istikrarın sağlanması ve ayrıcalıkların kaldırılması hedeflenmiştir. Temel hak ve hürriyetlerin korunması, eşit muamelenin yapılması, adaletin yerli yerinde dağıtımı, temel ihtiyaçların temini gibi konular sosyal adalet anlayışı üzerinden değerlendirilmiştir. İslam düşüncesinde ise bu temel yaklaşımların kapsamlı bir şekilde varlığından söz edilmektedir. İnsanın farklılığı, inanc1, kimliği, ırk1, statüsü ve güvenliği gibi birçok konular detaylı bir şekilde ele alınarak sosyal adaletin hakkaniyet ölçüsünde tesis edilmesi üzerinde durulmaktadır. Batı düşüncesinden farkı ise sosyal adaletin, bütün ahlaki değer ve normlarla ilişkili olarak ilahi bir kaynaktan beslenmesi ve bu ahlaki değerleri esas almasıdır.

Bat1 ve İslam düşüncelerinde, sosyal adalet yaklaşımının temelinde dünya görüşü ve medeniyet anlayışı gibi bazı farklılıklar bulunur. Batı düşüncesinde, toplumların ne istedikleri veya nasıl yaşamak istedikleri özelliklede son birkaç yüzyıl tartış1larak pragmatik olarak ele alınmış ve buna göre sosyal haklar tanzim edilmiştir. Piyasa ekonomisi içinde gerçekleşen adaletsizliğin sosyal ilkelere göre düzeltilmesi ise son dönemlerde ki çalışmalarla mümkün olmuştur. İslam düşüncesinde ise kutsal metinler (kitap ve sünnet) çerçevesinde detaylı olarak bireysel ve sosyal haklar belirtilmiş, insanın yaratılış gayesi ve mahiyeti esas alınarak sosyal haklar üzerinde durulmuştur.

Çalışmada kullanılan Batı kavramı belli bir yer veya sadece Avrupa kıtası olmadığı gibi İslam kavramı da sadece belirli toplumlar veya Şark değildir. Edward Said'e göre bu iki kavram tarihsel bir süreklilik içinde var olagelmiştir. Batı, kendisine ait bir gerçekliği ve mevcudiyet kazandıran bir tarih ve düşünce geleneğine, ortak bir imge ve kavram geleneğine sahip olduğu kadar İslam da kendisine ait gerçeklik, düşünce geleneği, ortak bir imge ve sözcük geleneğine sahiptir. Batı ile İslam arasındaki ilişkinin temeli ise bir iktidar ve egemenlik ilişkisi olarak görülmektedir (Said, 2003: 14-15). Bununla birlikte oryantalist varsayımların göre Batı, başlıca dini olan Hıristiyanlığı kabul etmesine karşın 
fazlasıyla ilerlemiş, İslam dünyası ise çeşitli kültür ve dillere sahip olmasına rağmen ilkellik ve gericilik batağına saplanıp kalmıştır. Bu varsayıma göre Batı moderndir, kendi parçalarının toplamından daha büyüktür. Kendini zenginleştiren farklılıklarla dolu olmasına rağmen kültürel kimlik olarak her zaman Batılı'dır. Fakat Batı'ya göre İslam dünyası, yüzeysel olarak Batı gibi birçok farklılıkları ve deneyimleri barındırmasına rağmen değişmez niteliklere sahip bir dinden öte bir şey değildir (Said, 2007: 82).

Niyazi Berkes ise Batı dünyasının kendine özgün yanlarını; bireyin özgürlüğü, kişisel hak ve hürriyetlerin üstün tutulması, akı1 karşısında geleneğin veya inancın boyun eğmesi, cehalete karşı pozitif bilimlerin başarısı olarak sıralamıştır. Bu özgün hümanist özellikler Batı'yı Doğu'ya karşı üstün kılmıştır. Fakat yirminci yüzyıl İslami düşünürlere göre Batı'nın özü hümanizm değil, Hıristiyanlıktır. Bu yönüyle Batı yalnız İslam'dan farklı olmakla kalmaz, onunla hiçbir zaman uyuşmaz bir uygarlık olarak sürüp gitmektedir. Batı Batı olarak, Doğu Doğu olarak kalacak ve asla birleşmeyecektir. Batı ile Doğu yani İslam, düşünceden yaşayışa ve ahlaka hemen hemen her yönüyle birbirlerinden farklıdırlar. Batı ve İslam uygarlıklarının problemlerinin kendileri de temelde farklılık gösterir. Örneğin Batı'da demokrasi ve sosyal adalet sorunu savaşlar ve mücadeleler sonunda ortaya çıkmıştır. Batı toplumu, eşitsiz, adil olmayan ve sınıf farklılığ üzerine kurulu olarak son yüz yıla kadar gelmiştir. Buna karşıllık İslam'da sınıf farklılığı olmadığı gibi eşitlikçi ve bireysel özgürlüğü benimseyen bir sosyal adaletin esasta var olduğu düşünülür. Bazı İslam düşünürlerine göre Batı'nın küresel anlamdaki üstünlüğü ise inandığı dinden veya bilimsel çalışmalardan kaynaklanmamaktadır. Bu üstünlüğün asıl sebebi Batı'nın dünyadaki birçok ulusu sömürerek hegemonik gücünü meşrulaştırmaya çalışmasıdır (Berkes, 2008: 415-417). Dünya'da yaşanan sosyal adaletsizliklerin temelinde de bu sebebin etkin olduğu düşünülmektedir.

Bu çalışmada, Batı ve İslam dünyasının sosyal adalete yaklaşımı öne çıkan bazı kişiler üzerinden incelenmeye çalışılmıştır. Dolayısıyla çalışmada izlenen yol, sosyal adalet ilkelerini net bir şekilde saptamak değil, son yüzyılda sosyal adalet üzerine söylem ve deneyimleriyle öne çıkan bazı düşünürlerin yaklaşımları değerlendirilerek, adil bir toplumun nasıl oluşturulabileceği üzerinde durulmuştur. Bunun için Batı düşüncesinde sosyal adalet, hâkim ve hegemonik bir paradigma olarak liberal adalet teorileri üzerinden ele alınırken daha çok David Miller ve John Rawls özelinde, toplumsal ve ekonomik eşitsizlikler üzerinden değerlendirmeler yapılmıştır. Rawls ve Miller'ın sosyal adalet yaklaşımları, toplumsal ve ekonomik eşitsizliklerin giderilmesini liberal düşünce ekseninde gelişen belirli haklar üzerinden açıklamaktadır. Çalışmanın ikinci kısmında ise Batı ve İslam düşünce sisteminin temelinde bir ahlak farkının olduğunu düşünen çağdaş İslam düşünürlerinden Kutub, Mevdudi ve Nursi'nin sosyal adalet yaklaşımları değerlendirilmiştir. Son yüzyılda Müslümanların giderek İslami prensiplerinden uzaklaştığı kaygısı ile İslami hareketlerin başında yer alan ve aynı zamanda yaşayan bu üç düşünüründen Kutub, Mısır'dan İhvan-1 Müslim hareketinin bir öncüsü, Mevdudi Pakistan'da Cemaat-i İslami'nin kurucusu, Nursi ise Türkiye'de Risale-i Nur hareketinin üstadı olarak kabul edilmektedir. Bu düşünürler son yüzyılda öne çıkan sosyal adalet tartışmalarını, liberal Batı1ı doktrinlere 
karşı İslam'ın kapsayıcı referanslarıyla açıklamaya çalışmaktadırlar. Batı'nın siyasal ve kültürel hegemonyasına maruz kalan Müslüman toplumların içinde bulunduğu siyasal, sosyal ve kültürel kırılmalarına karşı, bir kompleks ve reflekse değil aksine İslam'ın kendi öz referanslarıyla cevaplar üretmeye çalışmışlardır. Kutup ve Mevdudi, İslam'da sosyal adaleti daha çok siyasal ve yönetsel alanlarla ilişkili açıklarken, Nursi ise siyasi ve idari alanlardan uzak durarak birey ve toplum üzerinde değerlendirmeler yapmaktadır.

\section{Batı Düşüncesinde Sosyal Adalet Kavramı}

Batı düşüncesinde sosyal adalet, ilk olarak Platon tarafından dile getirilmiştir. Platon sosyal adaleti, herkesin yerli yerinde olması, herkesin hakkının verilmesi, toplumda belirli kişi ve gruplara hak ettiklerinin sağlanması şeklinde açıklamıştır (Yayla, 2000: 179). Aristo ise adaleti, ahlaki bir erdem olarak insanlara hak ettiklerini verme yani onlara hak ettikleri görevleri ve onuru, doğalarına uyumlu sosyal rolleri vermek anlamında kullanmıştır. Fakat Kant’tan Rawls'a liberal adalet teorileri hak edilişin doğalarına uygun değil seçimle ilgili olduğunu savunur. Hakları dağıtma insanların doğalarına uygun rollere uydurmak değil insanların rollerini kendi kendilerine seçmelerine izin vermektir (Sandel, 2015: 276).

Adalet (sosyal anlamda), Platon'dan itibaren bütün siyasal düşünürler tarafindan iyi bir sosyal düzenin asli niteliklerinden biri olarak kabul edilmiştir. Birçok düşünür iyi bir toplum ve adil bir toplumu benzer şey olarak kabul ederek adaleti, kapsamı en geniş sosyal ve siyasal bir erdem saymıştır. Bu açıdan sosyal adalet bir toplumdaki bölüşüm modelinin uygun hale getirilmesi anlamına gelmektedir. Batı düşüncesinde son yüzyıllarda gelişme gösteren sosyal adalet, iki temel kavram üzerinden tanımlanmıştır. Bunlardan ilki hak etme ve değer, diğeri ise ihtiyaç ve eşitlik kavramlarıdır. İlk temel kavrama göre, sosyal konum ve maddi ödül bir kişinin hak etme ölçeğindeki yerine uygun olmalıdır. Bununla kişiler yeteneklerine uygun işlerde bulunabilir. Dolayısıyla kişiler arasında firsat eşitliği sağlanarak ayrıcalıkların önüne geçilmiş olur. Sosyal adalete ilişkin ikinci temel kavaram olan ihtiyaç ve eşitlik ise toplumsal kaynakların kişilerin çeşitli ihtiyaçlarına göre eşit bir şekilde dağıttılması gerektiğini ifade etmektedir. Sosyal açıdan adil bir bölüştürme sağlandığında doğal olarak toplumsal huzur ve mutlulukta artacaktır (Miller, 1994: 14-18).

David Harvey, bu konuda başvurulabilecek genel kabul görmüş bir sosyal adalet ilkesinin bulunmadığını belirtir. Fakat yine de sosyal adalet kavramını, Aristo'nun ‘Etik'inden günümüze sosyal felsefi düşüncenin temelini oluşturduğunu aktarır. O’na göre sosyal adalet kavramının Batı'daki en önemli iki şekli; ilki toplumsal sözleşme olarak Hume ve Rousseau tarafından formüle edilmiş, ikincisi faydacılığın (Bentham ve Mill tarafından şekillendirilmiş) türevleridir. Yakın zamanlarda modern yorumlar sayesinde bunlara olan ilgi artmıştır. Rawls ve Miller gibi adalet üzerine çalışanlar, sosyal adalette eşitlik kavramını da irdeleyerek, gelirin ve toplumsal eşitsizliğin giderilmesi hakkında geniş yorumlar ortaya koymaktadırlar (Harvey, 2013: 94-95). Bu noktadan her adalet teorisi kendisine belli 
bir tür eşitliği referans alarak kendine özgü iddiasını, varsaydığı eşitlik anlayışı üzerine inşa etmektedir (Öztürk, 2014: 21).

Son yüzyılda önemi herkesçe ortaya konmaya çalışılan sosyal adaleti eleştirenlerin başında gelen Hayek ise bu kavramın eksikliklerini belirtir. Sosyal adalet, piyasa ekonomisi içerisinde adaletsizliklerin ve haksızlıkların oluşmasıyla bunun düzeltilmesine yönelik taleplerin toplumsala yönelik yapılmasını çağrıştırmaktadır. Dolayısıyla sosyal adalet, topluma yönelik yapılan bir çağrı olarak değerlendirilmektedir. Fakat sosyal adalet anlayışı, Hayek’e göre özgür bir toplumda boş ve anlamsızdır. Çünkü özgür bir toplumda hiç kimsenin iradesi değişik insanların iktisadi durumlarının ne olacağını belirleyemez. Bu açıdan Hayek sosyal adaletin ancak organizasyonlarda, yönetilen ve kumanda edilen bir ekonomi içerisinde anlamının olabileceğini belirtir. Çünkü organizasyon düzeninde hâkim olan adil ferdi davranış ilkeleri değil, belirli fertleri hedef alan, onlara görevler tahsis eden ve yön gösteren emirlerdir. Fertlerin durumları ve performansları, emirleri çıkartan merkez tarafindan değerlendirilir ve uygun görülen değer yargılarına göre onlara ne verileceği kararlaştırılır. Örneğin aynı işi yapan iki kişinin birbirinden farklı şekilde muamelelere tabi tutulması halinde daha aşağı derecede olan birinin adaletsizlikten söz etmesi ve adalet talebi anlaşılır olabilmektedir. Fakat özgür toplumda bu durum tamamen farklı bir şekilde fertlerin ve gurupların konumları herhangi birinin amaçlı bir ürünü değildir. İnsanlar arasındaki farklılıklar adil veya adil olmayan kavramlarla belirtilemezler. Hayek'e göre özgür bir toplumda fertlerin konumunu belirleyen süreç, beceriye ve şansa dayanan bir oyun gibidir. Bu oyuna katılanların aldatılması, kazananın ve kaybedenin olması sonuçları itibariyle normaldir. Bu oyunun sonuçlarını farklı oyuncular için adil olmasını istemek ise anlamsızdır (Yayla, 2000: 182-183).

\section{Modern Batı Düşüncesinde Sosyal Adaletin Gelişimi Ve Eleştirileri}

Sosyal ve siyasal kurumlara, özellikle çeşitli hak ve sorumluluklarına dair değerlendirmeler, genellikle adalet kavramlarıyla açıklanmaktadır. Adalet esas itibariyle, çatışan talepleri çözmek için bir ilke olarak düşünülmüş̧ür (Harvey, 2013: 94). Platon'dan beri bütün siyasal düşünürler tarafından iyi bir siyasal düzenin asli niteliklerinden biri kabul edilen adalet olgusu, iyi toplum ve adil toplumu aynı şekilde varsaymıştır. Bir diğer anlamda adalet kapsamı, en geniş bir siyasal erdem ve herkese hakkını teslim eden sürekli bir istenç olarak kabul edilmiştir (Miller, 1994: 14). Miller'a göre sosyal adalet, toplumdaki tüm bireyler için tesis edilmiş bir adalet olarak tanımlanır. Sosyal adalet günlük hayatta toplum için nelerin adil ve hak olup olmadığının anlaşılmasına yardım eder.

Modern Batı düşüncesinde sosyal adalet, daha çok 19. yüzyılın ilk zamanlarından başlayarak yaygınlık kazanmıştır. Dünyada sanayileşmenin gerçekleşmesi ve sonrasında hızla artması birçok toplumsal sorunları da beraberinde getirmiş, toplumların yaşayış şekli, emek, üretim ve hak edişlerini doğrudan dengesizleştirmiştir. Özellikle Batılı sanayileşme evresine giren ülkelerde görünen üretim 
ilişkileri yapısından, toplumsal ve düşünce yapısına kadar yayılan geniş toplumsal eşitsizlikler sosyal adaletin önemini arttırmıştır.

Batı toplumlarında daha çok sınıfsal noktadan belirginleştiren eşitsizlikler ve bunun ortaya çıkardığı sosyal adalet eksikliği algısı bu toplumlarda bazı düşüncelerin ve uygulamaların geliştirilmesinde son derece etkili olmuştur (Sunal, 2011: 302). Özelliklede Fransız Devrimi sonrası Batı'da hürriyet, eşitlik ve adalet prensipleri kamusal alanlarda yavaş yavaş uygulama firsatı bulmuştur. Üretim ve bürokratik araçları elinde bulunduran belirli kesimler veya sermayedarlar karşısında toplumun diğer çalışanları, ilerleyen dönemlerde belirli haklar elde etmişlerdir. Adil olmayan gelir dağılımı ve sosyal güvenlik gibi konular iyileştirilmeye çalışılmış, sosyal hayatta gelir dağılımının ve sosyal hakların düzenlenmeye başlanması ile bir takım özgürlüklerinde önünü açmıştır.

Fransız Devrimi'nin ardından devletin, özgürlüklerin önünü açması ile bireye tanınan hak ve özgürlüklerinin geliştirilmesi gerektiği üzerinde sıklıkla durulmuştur. 1791 Fransa Anayasası'nda bakıma muhtaç kişilere ve yoksullara yardım etmek, işsiz insanlara istihdam sağlamak üzere kurumsal düzenlemelere gidilmiştir. Sonrasında ise devletin vatandaşlarına kamusal hizmet ve yardım yapması kutsal bir borç kabul edilmiştir. Dolaysıyla devlet yoksul yurttaşlara yardım elini uzatacak, iş bulamayanlara iş bulacak, çalışamayacak olan vatandaşlarına da yaşayabilmeleri için gerekli imkânları sunacaktır. Yine bu dönemde devlet tüm vatandaşlarının eğitim görmeleri için imkânlar sağlayacaktır. Bu durum ile herkese sosyal hayata başlamadan önce eşit şans sağlaması amaçlanmıştır (Göze, 2013: 403).

Sosyal haklar bağlamında yapılan bu ilk uygulamalar sonrasında 19. yüzyılın sonlarına doğru devletin yüklendiği görevler, bireylerin eksikliklerini gidermek yönünde gelişmiştir. Devletin sosyal haklar konusundaki uygulamaları artmış, tüm toplumun refah içerisinde yaşamaya çalışması hedeflenmiştir. Özellikle II. Dünya Savaşı sonrası Batılı devletlerin öncülügünde gelişen sosyal devlet ilkesi, yeni anayasalarda yer tutmuş ve toplum için sosyal haklar ayrıntılı bir şekilde belirtilmiştir. Devlet artık vatandaşlarına her bakımdan maddi ve manevi gelişimlerini sağlama görevini yüklenmiş, bunun için gerekli ortam ve koşulları sağlamaya çalışmıştır (Göze, 2013: 404-412).

Tüm bu uygulamalar, sosyal adaletsizliklerin giderilmesi için bir araç olarak kullanılmıştır. Toplumda sosyal ve ekonomik açıdan güçsüz veya zayıfların, özetle eşitsizler arasındaki farkın giderilmesi ve toplumsal adaletin tesis edilmesi amaçlanmıştır. 1948 yılında Birleşmiş Milletler Genel Kurulu'nda kabul edilen İnsan Hakları Evrensel Beyannamesi'nin üye devletlerce resmileştirilmesi, özellikle sosyal adalet ilkeleri açısından önemli bir gelişme olmuştur. Herkesin adaletli koşullarda çalışma, işsizliğe karşı korunma, insan onuruna yakışır hayat sürme, barınma, beslenme eğitim alma ve kamu hizmetlerinden eşit faydalanma gibi birçok sosyal haklar bu beyannamede ulusların yasal mevzuatına girmiştir. Dolayısıyla sosyal hakların uluslarca güvence altına alınıp temin edilmesi günümüzde artık zorunlu bir durum haline gelmiştir. 
Günümüzdeki sosyal adaletin uygulanması, hakkaniyetli paylaşımın ölçütlerini ön plana çıkarmaktadır. Ayrıca adaletin sosyal ölçütündeki söz konusu paylaşım, şahısların hak edişlerine veya kabiliyetlerine de atıfta bulunmaktadır. Sosyal adalet kavramını eleştirenler, belirli bir ölçüde sosyal paylaşımın yanlış olduğunu ileri sürmektedirler. Örneğin bu adalet paylaşımı, kişinin kazanımlarının kapsamına, doğasına ve sahip olduğu kişilik özelliklerine bağlı olmasının yanlış olduğunu belirtirler. Özellikle Nozick, sosyal adaletin bu türden bir şablonla gerçekleştirilmesinin, şahısların özgürlüklerini haksız bir şekilde sınırlandırdığını ileri sürer. Bunun bir alternatifi olarak adaletin hak ediliş modeline göre meşru olan davranış biçimleri neticesinde elde edilmesi adildir. Bu açıdan adalet, şahısların önceden var olan ahlaki haklarını ihlal etmeyen bir ürün olarak değerlendirir (Campbell, 2008: 20). Hayek ise hem sosyal adaleti uygulamaya çalışıp hem de özgür bir toplumu oluşturmanın mümkün olmadığını yani kendi düşüncemizde sosyal adalete ne kadar çok yakınlaşmaya çalışırsak özgür toplumdan da o derece uzaklaştığımızı belirtir. Mutlak bir sosyal adaletin sağlanabilmesi için kendiliğinden oluşan düzeni bir organizasyon düzenine dönüştürmemiz gerekir. Sonuç olarak Hayek, sosyal adalet için yapılan birçok girişimin anti sosyal olduğunu ve toplum, içerisinde kendiliğinden oluşan sosyal güçlerini ve yapılarını bozduğunu savunur (Yayla, 2000: 195).

\subsection{David Miller’a Göre Sosyal Adalet ve Eşitlik}

David Miller, sosyal adalet tasarımının ilk olarak 19. yüzyılda ekonomi politiği içerisinde yer aldığını ve üretim faktörlerinin değişmesiyle toplumdaki paylaşım modelinin adalet ilkelerine göre uygun bir şekle getirilmesinin önemli bir gelişim olduğunu vurgulamıştır. Sosyal adaletin ilk olarak hak etme ve değer, ikincisi ise ihtiyaç ve eşitlik kavramlarını biçimlendirdiğini belirtmiştir. İlk görüşe göre toplumsal konum ve maddi ödül, bir kişinin hak etme ölçeğindeki yerine uygun olması gerektiği sosyal adaletin yeteneklere açık işlere veya firsat eşitliği istemlerini karşılaması gerektiğini vurgulamıştır. Ayrıcalıklı soy veya etniğin reddedildiği ve insanların değerlerini gösterebilme şansına sahip olacakları açık bir toplum üzerinde durur. Fakat değerin, uygulamada nasıl ölçülebileceği konusunda fikir ayrılıkları bulunmaktadır. Bazılarına göre değer, kişinin hangi yeteneklere sahip olduğu ve bunları ne kadar etkin kullanmasıyla ilişkilidir. Diğer bazılarına göre ise yeteneğin değerle fazla bir ilişkisi olmadığını ve insanların harcadıkları çabanın ödüllendirilmesi gerektiğini savunurlar. Fakat liberal düşünürler genelde serbest pazarı, uygulamada değeri ödüllendiren en iyi mekanizma olarak görmüşler ve kişinin ürettiği mal ve hizmet için isteyeceği hak edişin diğer kişilerce değerinin makul bir göstergesi olduğunu kabul etmişlerdir (Miller, 1994: 16-17).

Sosyal adaletin ikinci önemli unsuru olan ihtiyaç ve eşitlik ise malların veya hizmetlerin kişilerin gerekli ihtiyaçlarına göre dağıtılması gerektiği üzerine yoğunlaşır. İhtiyaçların başarılı ve tatmin edici bir şekilde dağıtımı, kişileri en azından maddi anlamda eşit kılmakta ve kişilerin beslenme, giyinme, barınma gibi hayattaki temel ihtiyaçlarının adil bir şekilde bölüştürülerek karşılanması hedeflenmektedir. Fakat bazı adalet kuramlarının ihtiyaç ve değerlere asli bir önem vermediği anlaşılmaktadır. Rawls ise alternatif bir kuram geliştirmiştir. Bu kuramın ayırt edici özelliği mal 
bölüşümünde eşitsizliğin, yalnızca toplumun en dezavantajlı kesimlerinden yana işlediğinde kabul edilebileceği ilkesini benimser. Bu özellik sosyal adalete eşitlikçi bir çeşit katar. Hayek ve Nozick gibi sosyal adaleti eleştiren ve yerine, hukuka ve yerleşik kurallara saygı biçimindeki geleneksel adalet anlayışına geri dönmeyi öneren teorisyenler durumu daha farklı bir noktaya taşırlar. Toplumsal adaleti, kaynakları dağıtan bir olgunun varlığı değil, bölüşüm modelinin kendilerinin de siyaseten değiştirebilecek olan temel toplumsal kurumlara dayalı olduğunu varsayarlar. Bu varsayımlar açısından sosyal adalet hakkındaki görüşler ve tartışmalar çoğunlukla adalete ilişkin görüşlerdeki gerilimi yansıtmaktadır. Adalet bir yandan kural ve usullere ilişkin olarak kişilere adil davranmak, kuralları usulünce uygulamak anlamına gelir ve kişiler özetle hak ettikleri veya ihtiyaç duyduklarına kavuşmalıdırlar (Miller, 1994: 17-19).

Miller'a göre sosyal adaletin en önemli iddialarından biri ise sosyal eşitliktir. İnsanların hayatlarındaki şanslarını etkileyen tüm kurumsal alanlarda yani eğitimden, iş hayatına, tüketim firsatlarından toplumsal hizmetlerin erişimine kadar birçok alanda eşit muamele görmeleri sosyal adalet açısından önemli bir gerçektir. Eşit muamele, Miller’a göre fırsat eşitliği ve çıktı (ürün) eşitliği şeklinde sınıflandırılır. Fırsat eşitliği, toplumsal fayda ve ödülleri elde etme şansının herkese eşit bir şekilde verilmesi anlamına gelir. Bu konuda bazı insanların karşısına yapay engeller çıkartılmamalı ve bazılarına ise haksız bir avantaj sağlayan ayrıcalıklar verilmemelidir. Çıktıların eşitliği bağlamında ise Miller, bu üç konuyu tartışmaya değer bulur. İlki neyin eşitliği sorusudur. Eğer insanlar maddi anlamda eşitleneceklerse, koşulları hangi bağlamda eşitlenecektir. İkincisi, ölçü meselesidir, belirli faydaların dağılımının eşit olup olmadığı nasıl karar verileceğidir. Üçüncüsü ise ahlaki konudur, yani çıktıların eşitliğine değer atfedilmesidir (Miller, 2008: 237).

Miller, fırsat eşitliği bağlamında insanların sosyal hayat içinde edindiği yer, sahip olduğu iş, kazandığ 1 para sadece kişinin kendi gayretleri, yetenekleri ve serbest seçimleriyle belirlenebileceğini savunur. $\mathrm{Bu}$ yaklaşım, insanların cinsiyet, ırk veya inanç farklılıkları nedeniyle iş hayatlarında engellemelerine olanak tanıyan biçimsel ayrımcıllı̆ın önünü kesmektedir. Fakat bazı kişilerce görünürde firsatlara eşit bir erişim olanağı gerçek bir firsat eşitliğini sağlamada yetersiz kalmaktadır. İnsanlara, hayattaki belirli şeyler için eşit bir şekilde başlama olanağı verilmeli, özellikle her bir çocuğa kabiliyetlerini geliştirecek eşit firsatların oluşturulduğu yaygın bir eğitim sistemi tanınmalıdır (Miller, 2008: 237).

\subsection{David Miller ve John Rawls'ta Sosyal Haklar ve Eşitlik}

Miller, sosyal adaletin insanlar arasında nasıl uygulanması gerektiği, avantajlı ve dezavantajlı konumdaki insanlar için nasıl düzenlenmesi gerektiği üzerinde geniş bir şekilde durmaktadır. Miller, bu avantajları en azından para, mal, mülk, iş, emlak, eğitim, sağlık hizmetleri, çocuk yardımı ve hizmetleri, insan yaşamına layık onur, ödül, güvenlik, konut, ulaşım ve eğlence olanakları şeklinde olması gerektiğini belirtir. Diğer yandan dezavantajlı durumları ise askeri hizmetler, zorluk, tehlike, kişi için 
sevilmeyen kötü iş, bakım ve yaşl11ık olarak sıralamaktadır. Miller, toplumda bulunan bu avantaj ve dezavantajları iyi veya kötü şeklinde ayırmaktadır. Sosyal adaletin bir açıdan refah anlamını çağrıştırdığını fakat bu refahın tek başına anlaşılmaması gerektiği üzerinde durur (Miller, 2003: 7). Bu refah durumu dezavantajı bireylerin çalışma ve motivasyonlarıyla da ilişkilidir. Çünkü toplum içinde dezavantajlı birey veya gruplar kendilerini sayg1 duyulmayan adaletsiz bir noktada görmekte ve motivasyonları negatif etkilenmektedir (Tyler, 2003: 352-353).

Miller, maddi eşitliği her vatandaş için adil bir noktada değerlendirir. Maddi eşitliğin sağlanmasında hükümet politikalarının başarısı büyük öneme sahiptir. Ancak bu maddi eşitliğin sağlanması ile insanların refahtan eşit düzeyde yararlanmaları, kaynakların adil dağıtılması ile ilişkilidir. Miller, bir anlamda Rawls'a yakın olarak toplumsal firsatların ve özgürlüklerin, her vatandaş için adil bir şekilde dağıtılmasını sosyal bir özgürlük ideali olarak görür. Miller'ın öne sürdüğü firsat eşitliği ilkesine göre dezavantajlı ve güçsüz bireylerin ayrımcıllğa uğramadan sosyal olanaklardan kendi kabiliyetleri nisbetinde faydalanmaları gerekir. Bu bağlamda Rawls’ta firsat eşitliğini, toplumda dezavantajlı durumda olan kişilerin maksimum faydasına olacak şekilde düzenlenmesini savunmaktadır. Dolayısıyla sosyal ve iktisadi eşitsizlikler, en kötü durumdaki kişilerin yararına göre düzenlenmelidir. Rawls, Miller'den farklı olarak doğal kabiliyetlerin ve toplumsal koşulların bir şans meselesi olduğu eşitsiz durumdaki insanların hak taleplerinin şansa dayanmaması gerektiğini belirtir. Rawls, bunu mutlak eşitlik talebi olmayan fark ilkesi olarak ileri sürer. Miller ise insanların kötü şanstan sakındırılmaları gerektiği, eğer insanlar şanslı ise yani yetenek ve çabaları nedeniyle nisbi ölçüde bir ödülü hak etmelidirler. Bu durum eşitsiz görünse bile adil olarak değerlendirilir.

Çünkü Rawls'ın adalet ilkesinde eşit temel özgürlükler bulunmaktadır. Bu özgürlükler, politik özgürlükler yani seçme ve seçilme hakk1, konuşma ve toplantı yapma hakk1, vicdan özgürlüğü ve düşünce özgürlüğü, kişisel mülkiyeti koruma hakkı olarak belirtilir. Rawls'ın özgürlüğün önceliğinde anladığı şey, eşit temel özgürlüklerin teminidir. Fakat Rawls’ta öncelikli olan özgürlüğün değil hakların ve hukukun önceliğini benimsenmesidir. Ona göre genel refah düzeyi yükseldikçe, geriye sadece daha az acil ihtiyaçlar kalır ve aynı zamanda eşit özgürlüklerin uygulanması önündeki engeller kalkar. Kısacası Rawls, toplumsal adalet ilkelerini toplumun çeşitli sektörleri arasındaki toplumsal ve ekonomik farkl111kların giderilmesinde önemli bir araç olarak görür (Hünler, 1997: 99-102).

Rawls, adaleti sadece temel kaynakların (her türlü zorunlu olan insani ihtiyaçların) dağıtımı ile ilgili olması gerektiğine kapı açar ve insanın nihai iyiliğini bir kenara koyarak ahlaki değeri görmezden gelir (Fleischacker, 2013: 210-213). Bu açıdan Rawls'ın adalet anlayışı liberal düşünce ekseninde gelişen iki ilkeden oluşur. Birincisi, her insanın bütüncül bir (liberal) sistem içerisinde diğerleriyle benzer ve eşit haklara sahip olmasıdır. İkincisi ise en dezavantajlı olan bireye en büyük faydanın sağlanması ve adil firsat eşitliği gereğince toplumsal ve ekonomik eşitsizliklerinin giderilmesidir (Peffer, 2001: 363). Dolayısıyla Rawls, Kantçı bir çizgide ilerleyerek makul çoğulculuk ve işlerliği olan liberal bir sistem içerisinde siyasal doğruluk (hak) ve adalet kavramının geliştirilmesini zorunlu görür. 
Bundan hareketle adil bir toplumun meydana gelmesi için ise liberal ve düzgün (adil) halkalar topluluğunu oluşturulmasını ön görür. Ütopik bir yaklaşımla, siyasal liberalizmden makul bir 'Halkların Yasası'nı geliştirerek bütün dünyada hâkim olan liberal ve adil halkalar topluluğu meydana getirilebileceğini iddia eder (Rawls, 2006: 20-23).

Son dönemin en önemli adalet teorileri, maddi adalet ölçütünü sözleşme düşüncesiyle birleştirmektedir. Rawls'a göre adaletin, toplum için hakkaniyetli bir durum dâhilinde neyin adaletli olduğuna dair herkes için temel özgürlüklerin en geniş anlamda tesis edilmesiyle birlikte, sosyal ve ekonomik eşitsizliklerin giderilerek en dezavantajlı kesimlerin yararına olmalıdır. Sosyal hayatta, insanlar arasında adil firsat eşitliği ilkelerine uygun biçimde herkese açık mevki ve görevlerin sağlanması da sosyal adaletin dağıtımı için gereklidir (Campbell, 2008: 20). Rawls'a göre adalet üzerine düşünürken özel amaçların, bağl11ıkların ve iyi anlayışının bir kenara bırakılması gerekir. Yani bu “bilgisizlik peçesi”nin ardından adalet üzerine düşünmek doğru (hak) bir anlayıştır.

Miller, sosyal adaletin tesisinde ise temel insani ihtiyaçlara dikkat çekerek bu ihtiyaçların önemine vurgu yapar. Ona göre, her vatandaşın temel ihtiyaçları yeterli bir şekilde karşılanarak, bulunduğu toplumda onurlu ve güvenli bir yaşamı elde etmelidir. Güvence altına alınan temel insani ihtiyaçlarıyla bireyler yaşamını sürdürmeyi sağlayarak kaynaklara kolay erişebilmelidir. Miller'ın bu ilkesi ekonomik ve sosyo kültürel hakların da bir gereğidir. Miller, bu açıdan Rawls’tan daha belirgin bir şekilde doğal yaşam alanları ve çevresel hakların üzerinde durmuştur. Rawls, adalet teorisinde doğal çevreyi sadece kısaca belirtirken, Miller ise fiziksel çevrenin korunmasını da bir sosyal hak olarak geniş bir şekilde ele almıştır. Çünkü insanların temiz, güvenilir ve yaşanabilir çevrede yaşam sürmelerini minimum bir sosyal hak olarak belirtir. Bu açıdan Miller, faydacıllk üzerine doğal kaynakların kullanımını eleştirir. İnsanlara, doğal çevrenin kullanımında maksimum özgürlük ve hareket sahasını vermenin doğru olmadığını açıklar (Miller, 1999: 155-159).

\subsection{David Harvey'e Göre Sosyal Adalet ve Adil Dağıtım}

Sosyal adalet, David Harvey'e göre bireysel ilerleme arayışı ile toplumsal iş birliği yapma zaruretinden ortaya çıkan çatışmalar için adil ilkelerin uygulanmasıdır. Sosyal adalet ilkesi, bütün olarak toplum hayatında, ortak bir eylem ve hareket sürecinden doğan faydaların ve yükümlülüğün dağıtımında uygulanır. Bununla birlikte üretim ve dağıtım faaliyetleriyle ilgili toplumsal ve kurumsal düzenlemeleri de kapsar. Dolayısıyla sosyal adalet, faydanın toplumsal bireylere dağılımını hakkaniyet çerçevesinde belirler. Bununla birlikte bütün bireylere, gruplara, örgütlere ve bölgelere uygulanan dağıtım, adil yollarla ve adil bir şekilde sağlanır (Harvey, 2013: 94).

Sosyal adalet, ilke olarak toplum arasında sağlanan adalet olduğu gibi bireyler arasındaki adaletin tesisini de vurgular. Modern anlamda sosyal adaletin tesisinde dağıtıcı adalet kavramı karşımıza çıkar. Herkesin belirli bir düzeyde haklara sahip olabilmesi, maddi şeylerin bireylere layık olduğu kadar dağıtılması ve herkesin sahip olması gereken şeylerin temini dağıtıcı adaletin ilkelerinden sayılmıştır. 
Herkesin refahtan tam yararlanması için devletin bir şekilde görev alması bu ilkeler açısından gereklidir. Dolaysıyla bu hakların bireylere dağıtımı bir lütuf şeklinde değil layık olunduğu için icra edilmelidir (Fleischacker, 2013: 19-20). Bunlar esas olarak bireylerin içinde yaşadıkları ve çalıştıkları toplum üzerindeki taleplerin neyin meşru kıldığıyla ilgilidir. Harvey (2013: 97-98), bunu maddeler halinde ilk olarak temel eşitlik kuralı ile her bireyin sosyal faydalar üzerinde katkısına bakılmaksızın eşit düzeyde yararlanabilme haklarının olduğunu belirtir. Harvey, sosyal adaletin özünü ihtiyaç, liyakat ve ortak yarara katkı ilkeleriyle tanımlamış ve kıt kaynakları, sosyal adaleti yüksek düzeye çıkaracak şekilde bir yönetim sorunu olarak değerlendirmiştir. İnsanların gıda, konut, sağlı hizmetleri, eğitim, toplumsal ve çevresel hizmetleri, tüketim malları, yaşam konforu, ulaşım hizmetleri gibi çeşitli kategorilerde asgari ihtiyaçlara sahip oldukları ve bunların adilce sağlanması gerektiğini ileri sürer. Sosyal adalette adil yolarla sağlanmış bölgesel bir adil dağıtımın üzerinde duran Harvey (2013: 111), gelir dağıtımı açısından her bölgedeki nüfusun ihtiyaçlarının karşılanması ve kurumsal, örgütsel, siyasal ve iktisadi açıdan en az avantajı bölgelerin refah düzeylerinin artırılması gerektiğini belirtir. Fakat Harvey (2013: 108), kapitalist sistem içerisinde sosyal adaletin tam sağlanmayacağını iddia eder. Çünkü kapitalist araçlar kendi kapitalist amaçlarına hizmet ederler. Dolayısıyla bu kapitalist amaçlarla sosyal adalet hedeflerine ulaşılamaz.

\section{3. İslam Düşüncesinde Adalet, Sosyal Adalet Ve Eşitlik Kavramı}

İslâm düşüncesinde adâlet, öncelikle ontolojik bir kavram olarak ele alınmıştır. Buna göre Allah'ın adaleti, var olan her şeye varlık hiyerarşisi içindeki durumuna göre tamlık ve mükemmellik kazandırmasıdır. İlahi inayete bağlı olarak adaletin, varlık sahnesinde yer alan her varlığın bütün gelişim safhalarında ve hatta her noktasında tecelli ettiği belirtilmiştir (Çağırcı, 1988: 342). Etimolojik olarak ise adalet, Arapçada "adl” kelimesinden gelmektedir. Kavram olarak adl, "adale” fiilinden türeyen soyut bir isimdir. Bu kavram düzeltmek, doğru oturmak, tadil ve tashih etmek, yanlış yoldan doğru yola geçmek, eşit, muadil olmak, dengede tutmak, dengelemek, tartmak gibi anlamlara gelmektedir. Geniş anlamda ise adalet, hakka riayet, dengeyi gözetmek, itidalli olmak, doğru yoldan sapmamak gibi bireysel ve sosyal değerlerin bir bileşkesidir. Dolayısıyla İslam'da adalet kavramı genel olarak doğruluk, muvazene, ölçü, itidal ve insaf gibi anlamları ihtiva eden, ilahi olan bütün değer ve faziletlerin bir sentezi olarak anlaşılmaktadır (Hadduri, 1999: 22-25).

İslâm düşünürleri, insanın ahlâkî mahiyetini nizam fikrinden hareketle açıklarken bu alandaki adâleti, insanda bulunan temel faziletlerin uyumlu bir sonucu saymışlardır. Eflatun'dan beri devam eden ve İslâm düşünürlerince bazı değişikliklerle benimsenen görüşe göre, insanın düşünme veya bilgi gücü (kuvve-i akliye), öfke gücü (kuvve-i gadabiye) ve şehvet gücü (kuvve-i şeheviye) olmak üzere üç temel gücünden üç fazilet doğar. Bunlar sırasıyla hikmet, şecaat ve iffettir. Adâlet ise bu üç faziletin gerçekleşmesiyle kazanılan ve hepsini içine alan dördüncü temel fazilettir. İslâm literatüründe, ilk üç faziletten her biri zaman zaman farklı kavramlarla ifade edildiği halde, dördüncü fazilet her zaman adâlet olarak tanımlanmıştır. Dolayısıyla adalet, hem bireysel hem de toplumsal noktada istikrarlı bir doğruluk 
ve ahlak kanununa itaatle gerçekleşen ruhi denge ve ahlaki bir erdemdir. Eflatun ve Aristo tarafından üzerinde durulan "her fazilet, ifrat ve tefritten ibaret iki reziletin ortasıdır" şeklindeki görüşü, İbn Sina ve İbn Miskeveyh gibi bir kısım İslam düşünürü tarafindan ilk üç fazilet yani hikmet, şecaat, iffet ile birlikte adalet faziletine de tatbik edilmiştir. Buna göre adalet, zulüm ile inzılam (zulüme boyun eğme) diye tarif edilen iki reziletin ortası olduğu belirtilmiştir. Buna karşılık Gazzali ise adaletin kaybolması ile sadece zıddının ve karşııının ortaya çıkacağını belirtmiştir. İbn Sina ise sosyal hayatın oluşması ve sağl1klı bir şekilde devam etmesini kanun (Kur'an ve sünnet) ve adalet prensiplerine uygun düzenlenmesine bağlamıştır. Bunu uygulayacak kişinin ise doğru ve güvenilir yani salih bir insan olması gerekir. Bu şekilde cemiyet içinde huzurlu bir düzenin ve sosyal adaletin sağlanmasını mümkün görür (Çağırc1, 1988: 342). Gazzali’ye göre adalet kavramı, ancak İlahi adaletin ne anlama geldiğini bilmekle yani Allah'ın fillerini ve yaratıp idare ettiği kâinatı tanıyarak anlaşılacağını belirtmiştir (Topaloğlu, 1988: 387). Çünkü varlık dünyası gerçek anlamda tanındıkça insanlar arasında adalet hakikati anlaşılacak ve uygulanabilecektir.

Esas olarak izafi bir kavram olan adaletin kriterleri farklı toplumlarda değişiklik gösterebilir. Fakat bu değişikliklerde bazı ortak unsurlar bulunmaktadır. Bunlar bireysel veya müşterek faydanın belirlenmesi ve ihtiyaç duyulan şeylerin neler olduklarıdır. Buna bağlı olarak insanlar bulundukları toplum içinde belirli bir adalet standardının veya bazı adalet standartlarının gelişmesine elverecek bir sosyal düzen kurabilirler. Bu şekildeki adalet kusurlu olsa da insanlar onu değişen sosyal düzen içerisinde iyileştirmeye çalışırlar. Bu tür adalete pozitif adalet denmektedir. Miller ve Rawls gibi düşünürlerinin sosyal adalet kuramları bu kategoriye girmektedir. Diğer yandan insanın kusurlu ve zayıf olduğu kendi çabalarıyla her türlü sorunların üstesinden gelemeyeceğini inanan toplumlarda adalet standartlarını belirleyerek sosyal düzenin kaynaklarını ve temel ilkelerini saptamak için ilahi bir otoriteye başvurulur. Böylesi bir kaynaktan ortaya çıkan adalete saygı duyulmakta ve adalet dağıtımında uzun ömürlü olduğu düşünülmektedir. İlahi bir kaynaktan ortaya çıkan adalet, pozitif adaletten farklı olarak ilahi veya vahyi adalet şeklinde tanımlanır. İslamiyet bu tür adaletin kategorisine girmektedir. Aristo, din ile ahlakın iç içe girdiği bu tür adaletin insansı değil doğal güçlerin bir ürünü olması anlamında "doğal adalet" tabirini kullanmıştır. Aristo’yu takip eden birçok düşünür çoğunlukla doğal adaleti ilahi adalet ile bir tutmuştur (Hadduri, 1999: 17-19).

İslâm düşüncesine göre sosyal düzenin inşasında, adâletin yakından ilgili olduğu diğer bir kavram ise eşitliktir. Farabi’nin belirttiği gibi adâlet, erdem ve fazilet sayılan, bir kısmı kişinin kendisinden başkasını ilgilendirmeyen, bir kısmı da diğer insanlarla münasebetlere yansıyan niteliklerin ikinci grubuna girer. Bu sebeple sosyal adâlet, servet ve imkânların paylaştırılması, alışveriş gibi sosyal ilişkiler ile zulüm ve haksızlığa konu olabilecek diğer uygulamalarda söz konusudur. Dolayısıyla sosyal adâlet, ortak faydanın dağıtılması ve bu payların korunmasına ilişkin olmak üzere iki kategoriye ayırmıştır. Bu alanlarda eşitliği gözetmek sosyal adâletin gereğiyse de bu mutlak ve ütopik bir eşitlik değildir. Çünkü İbn Miskevehy’e göre bir mühendis az iş yaptığı düşünülse de onun bu çalışması yaptığı 
projeyi uygulayan işçilerin çok çalışmasına denktir (Çağırcı, 1988: 343). Bu bağlamda ferdin toplum içindeki iktisadi ve sosyal durumuna bakılmaksızın herkese insanca yaşama, temel ihtiyaçlarını sağlama imkânı veren sosyal adalet anlayışında ölçü eşitlik değil, dengedir (Karaman, 1988: 343).

İslam'ın sosyal adalet prensiplerinde, toplum içerisindeki fertlerin maddi ve manevi seviyesini yükseltmek, güçlendirmek, fertlerin mutluluğunu arttırmak, ferdin insanlık şerefini korumak, kabiliyetlerini geliştirmek esastır. Bununla birlikte fertlerin akıl ve bedeni güçlerini toplumun faydasına kullanmaya yönlendirerek onlara yardım etmektedir. Bu açıdan İslam'ın ortaya koyduğu toplumsal hakların en önemlisi fertlerin eşitliği ve hürriyetinin korunmasıdır. İslam dini, fertlerin bu sosyal haklarını bütün insanlık için de gerekli görür (Udeh, 1968: 21). Çünkü bütün insanlar, kanun önünde eşittirler ve kişi hak ve hürriyetleri koruma altındadır. Fertler arasında cinsiyet, ırk, renk, dil ve din esasına göre kesinlikle biçimsel ayrım yapılamaz. Her fert, fırsat eşitliği ilkesiyle ve diğer fertlere tanınan firsatlar ve imkânlar çerçevesinde kamuya ait maddi kaynaklardan yararlanma hakkına sahiptir. Kişinin gayret ve emeği nispetinde bir hak edişi vardır. Bu hakkın korunması ve insan onuruna yaraşır bir yaşam standardına ulaşması temin edilir. Bununla birlikte kişi kamu hizmetlerinde kabiliyet ve liyakatine göre bulunabilir (Akgündüz, 1997: 104-122).

İslam dünyasında, modern dönemde sosyal adaleti içine alan hukuki ve yasal düzenlemeler özellikle on dokuz ve yirminci yüzyılda yoğunlaşmıştır. Batı, özellikle de Batı'nın pozitif hukuku ve onu besleyen hukuk doktrinleri karşısında konumunu sorgulayan İslam dünyası, Müslümanların yeniden yükselişe geçmeleri ve adil bir kamu düzeni için kitap ve sünnet çerçevesinden çareler aramışlardır. Modern anlamda ilk defa Osmanlı Devleti'nde "Mecelle" ile bireysel, sosyal ve iktisadi hayata ilişkin hükümler içeren hukuki düzenlemelere girişilmiştir. Bu düzenleme yirminci yüzyılda İslam ülkelerinde hazırlanan kanunlara da örnek teşkil etmiştir. Bu dönemde şekillenen liberal ve modernist sosyal adalet anlayışı karşısında İslam dünyasında Kur'an'ın ahkâmının sosyal adalete ilişkin sıkı bir bağının bulunduğu kabulüne dayanan görüşler ortaya atılmıştır (Özcan, 2001: 41).

Yirminci yüzyılda bazı İslam ülkelerinde ortaya çıkan İslami hareketler ve önde gelen temsilcileri sosyal adalet hakkında özde çelişkili olmayan fikirler beyan etmişlerdir. Batı'nın siyasi ve sosyal hegemonyasına karşı yirminci yüzyılın ortalarında Mısır'da ortaya çıkan İhvan-1 Müslimin hareketi Seyyid Kutub ile Arap ülkelerinde geniş bir ilgi görmüştür. Batı tahakkümüne karşı İslami tavrı ile bu hareket tıpkı Pakistanlı Mevdudi'nin Cemaat-i İslami'si gibi İslam'ın inanç esasları çerçevesinde siyasi, hukuki ve iktisadi uygulamalar ekseninde bağımsız ve evrensel bir hayat görüşü ortaya koyma yönünde faaliyet göstermiştir (Özcan, 2001: 38). Said Nursi'nin başlatmış olduğu Risale-i Nur hareketi ise Türkiye'de, Cumhuriyet döneminde gelişen Batıcı çağdaş değerler karşısında İslam'ın kapsayıcı karakteristiğini ortaya koymaya çalışırken bunu siyasi bir şekilde değil bireyde tahkiki olarak tevhid inancının içselleştirilmesiyle başarmayı hedeflemiştir. Nursi, Osmanlı'nın son döneminde başlayan Batılılaşma hareketinin Cumhuriyet dönemindeki radikal reformlarla İslami kurum ve normları geriye bırakmasını Batı medeniyet ve doktrinlerini eleştirerek yapmaktadır. Dolayısıyla bu üç hareketin ileri 
gelen düşünürleri genel anlamda, İslam toplumları içerisinde benzer özellikler taşıyan ve aynı sosyal sorunlara ve sosyal adaletsizliklere karşı dikkat çekici açılımlar yaptıklarını söylemek mümkündür.

\subsection{Seyyid Kutub'a Göre Sosyal Adalet}

Batı dünyasının özde hiçbir zaman dinin varlığını kabul etmediğini belirten Seyyid Kutub, İslam'da pratik hayat, dinin ortaya koymuş olduğu gerçekten farklı ve ikiye bölünmüş olmadığını belirtir. İslam'ın görevi, insanı toplum içerisinde kâmil bir şekilde ortaya koymak olduğundan, İslam'ın pratik hayattan uzaklaşıp beşer vicdanına hapsedilmesi mümkün değildir. Çünkü İslam'ın çalışma alanı insanlığın tüm sosyal, hukuki ve iktisadi hayatıdır. Bu nedenle Kutub'a göre İslam'da sosyal adalet anlayışı insan hayatının tüm yönlerini ve temel ilkelerini içine alan kapsamlı bir adalettir. Sınırlı iktisadi bir adaletten çok farklı olarak hayatın görünen tüm yönlerini ve tüm çalışma alanlarını kapsamaktadır. Ayrıca bu adaletin kapsadığı değerler sadece iktisadi değerler olmadığı gibi genel anlamda maddi değerlerde değildir. Sosyal adalet tüm değerleri içine alan bir adalet biçimidir (Kutub, 2014: 19-51). Dolayısıyla Batı doktrinlerinin sosyal adalet konusunda sahip olduğu faydalı prensiplerin tamamı İslam'da mevcuttur (Hadduri, 1999: 244).

Kutub'a göre (2014: 52) İslam, sosyal adaleti gerçekleştirmek için iki ana çizgi üzerinde hareket eder. İlki mutlak bir tevhid inancı diğeri ise bireyle toplum arasında sosyal güven veya emniyeti teminat altına almaktır. İslam, bunu tesis ederken insanın sahip olduğu kişilik ve benlik duygularını göz ardı etmez. Çünkü Kur'an, insanın kendi hırsı ile ciddi zararlar verebileceğini, cimri ve egoist davranabileceğini ve zulüm ve adaletsizlik yapabileceği ayetlerde çokça belirtmiştir. Bu açıdan insanın kendi çıkar veya faydalarını ön planda tutması karşısında yine zekât ve yardımlaşmamın tesis edilmesi, yardıma muhtaç olanlara yardım edilmesi, kimsesiz ve zayıfların, ihtiyar ve kadınların korunması ve onların haklarına riayet edilmesi gerektiği, insanların birbirleriyle münasebetlerinde tartıya ve ölçüye adilane riayet etmeleri gerektiği, dengeli bir hayat yaşamayı tavsiye ederek genel anlamda sosyal adaleti vurgular.

İslam, birey ve toplum arasındaki firsat eşitliği ve adalet ilkelerinin temellerini açık ve kesin bir şekilde belirlemiştir. Kişilerin ve toplumların ilerlemeleri için çalışmaları ve gayretleri teşvik edilmiştir. Kişinin çalışmasına engel olacak hiçbir şey önüne çıkartılamaz. Hiç kimsenin önünde asil bir aileden gelme, ırk, cinsiyet gibi şeyler ayrıcalıklar şeklinde konulamaz. Kısacası İslam, kişiye yetecek kadar bir imkânı, aralarında adaleti sağlamayı ve bu kapsamda gelişip büyümelerini teminat altına almaktadır (Kutub, 2014: 58-59).

$\mathrm{Bu}$ teminatı ilk olarak en açık şekilde İslam Peygamberi döneminde görmek mümkündür. Peygamberin ilk yaptığı işlerden biri olarak Medine'ye hicret eden muhacirleri yerleştirmek, onların ve ailelerinin temel ihtiyaçlarının karşılanması için gerekli tedbirleri almak olmuştur. Bu amaçla Müslümanlar arasında sosyal ve ekonomik bir dayanışma ve yardımlaşma tesis edilmiştir. Bu toplumsal yapının sosyal hak ve sınırlıkları, İslam peygamberinin öncülüğüyle ortak bir mutabakat yani anayasa 
denilebilecek Medine Vesikası'yla temin edilmiştir. Böylece Müslüman halk ile diğer farklı kesimlerce toplumsal yapı ve ilişkiler hukuki zemine oturtulmuştur. Toplumun farklı inanç ve kesimleri arasında güvenli sosyal bir adalet tesis edilmiştir. Bu vesikaya taraf olanlar arasında adalet ve hakkaniyet ilkeleri benimsenerek sosyal olarak bir arada yaşama gayreti geliştirilmiştir. "İslam, sosyal haklar anlamında memleket, sınıf ve ırk farkı gözetmeksizin insanlar arasında tam sosyal bir eşitlik tesis ederek bir dünya topluluğu meydana getirmeyi hedeflemiştir” (Hamidullah, 1965: 166). Üstünlüğün sadece güzel ve iyi davranışlarla sağlandığı (Hucurat Suresi: 11) ve İslam peygamberinin ise (hadislerle) insanların en iyilerinin yine insanlığa ve insanlara hizmet eden ve fayda verenlerle ilişkili görmesi bu durumun özünü ortaya koymuştur.

Kutub, İslam'ın sosyal hayata ve adalete bakışının kapsayıcı olduğunu belirtir. İnsanların sosyal hayatına yardımlaşma ve dayanışmayı esas olarak koyan İslam, bunun ile sosyal adaleti tesis eder. İslam'ın öngördüğü adil bir sosyal düşünce, insanlar arasında esas itibariyle kişisel mülkiyet düzeni, miras hukuku, zekât düzeni ve buna bağlı olarak İslam'ın kapsamında yer alan tüm düzenleri açıklamaktadır (Kutub, 2014: 63-110). İslam düşüncesinde doğal kaynakların toplum faydasına kullanımını, kamu yararı ve toplum refahının yükseltilmesi benimsenir. Çünkü İslâm toplum düzeni, Allah'ın iradesi ve adaletinden gelen bir adalet ölçüsü üzerinden bir kamu düzenine sahiptir. Bu kamu düzeni hem toplumun huzur ve barışı hem de diğer toplumlarla olan ilişkilerin düzenlenmesi için gerekli olan prensipleri içermektedir. İslâm toplum düzeninde, toplum (ümmet) Allah'ın adaletinin öznesi, bütün diğer toplumlarda ise toplum adaletin nesnedir (Hadduri, 1999: 184). Bu açıdan İslam düşüncesinin hem fertleri, hem toplumları, hem milletleri hem de gelecek nesilleri kapsayacak geniş bir bakış açısına sahip olduğu belirtir.

Kutub, İslâm'ın bu geniş bakış açısıyla sosyal adalet için belirlediği üç esası; mutlak vicdan hürriyeti, mükemmel insani eşitlik, sağlam ve güvenilir bir sosyal dayanışma olarak sıralamıştır. Batı düşüncesinde salt maddeci veya iktisadi ölçülerin temel alındığını belirten Kutub, vicdani hürriyetin tüm değerleri ile insani eşitliğin önemini vurgular. Batı'nın ulaşmak istediği salt iktisadi eşitliğin ise sınırlı olduğunu, İslam'da ise insanların sadece iktisadi noktadan eşitliliklerinin söz konusu olmayıp mükemmel anlamda kapsayıcı bir eşitliğin bulunduğunu belirtir. Bu eşitlik ve özgürlük mutlak anlamda sınırsız değildir. Bu tarzda bir düşünce hem bireyin hem de toplumun yıkılması için yeterlidir. Toplumsal dayanışmanın ilk basamağını oluşturan bireylerin kendi sorumluluk alanlarını bilerek İslam'ın emretmiş olduğu sosyal yardımlaşma prensipleriyle hareket etmeleri sosyal adaletin tesisi için gereklidir (Kutub, 2014: 63-110).

İslam hukukunun gayelerinden en önemlisi insanlar için faydalı olanın ikamesidir. Ancak bu fayda Batı düşüncesindeki faydacıların belirttiği gibi salt maddi boyuta indirgenmiş bir faydadan farklıdır. Bireyin ve toplumun huzurunu temin eden dini, siyasi, sosyal ve ahlaki boyutları olan bir olgudur. Bununla birlikte toplum düzenini sağlamak bu faydaların gerçekleştirilmesine ve zararlarından da kaçınılmasına bağlanmıştır. Bu sebeple İslam, bireyin sahip olduğu hak ve hürriyetleri "maslahat 
hassa" ve "maslahatı amme" ilkeleri etrafında belirlemektedir. Hukukun amaçları ile özgürlük ve eşitlik ilişkisinin değerlendirilmesi de söz konusu ilkeler çerçevesinde şekillenmektedir (Bilgin, 1996: 213214). Bu açıdan Kutub'a göre İslam, sosyal adaleti kapsayıcı bir şekilde gerçekleştirmeye çalışırken, onu sadece iktisaden sınırlı bir adalet olmasının üstünde bir yerde olduğunu belirtmiştir. İslam'ın ortaya koymak istediği sosyal adalet, insanlık açısından kapsayıcı olmayı veya tam kapsamlı bir adalet yapmayı hedeflemiştir. Bunu da iki temel üzerinden sağlamaya çalışmıştır. Birincisi insanın ruhi derinliklerine dayanan vicdan, diğeri ise sosyal alandaki yasal yükümlülüktür. Bu iki güç arasında meydana gelen bağl1lıkla insan üzerinde pozitif etkiler görülebilir. Bu durum sosyal adaletin sağlanmasında temiz bir vicdan ile sağlam ve güvenilir temellere oturtulmuş insani bir dayanışmayı da beraberinde getirir (Kutub, 2014: 140-148).

Kutub'a göre İslam, birey ve toplum için neleri amaçlamış ise bu hedefleri gerçekleştirmeye doğru ilerler. Bireye, kendisine tanınmış olduğu sınırlar çerçevesinde, kimseye zarar vermeyecek hakkaniyet ölçüsünde kendi özgürlügünü yaşama hakkını tam anlamıyla tanır. Kişinin, kendi özgürlüğünü kullanırken toplumsal haklara zarar vermemek koşuluyla hareket etmesi gerekir. İslam düşüncesinde kişinin, toplum içerisinde hangi sosyal haklara sahipse onları ortaya koyarak toplumdan bu sosyal hakların karşı1lıklı olarak yükümlülüklerini ve görevlerini yerine getirmesini, bu hakların korunmasını ister. Bu şekilde toplum içinde güvenli, huzurlu ve faydalı hedeflere erişilebilmesi beklenir (Kutub, 2014: 137).

\subsection{Ebu'l A'la El Mevdudi'ye Göre Sosyal Adalet ve Eleştirisi}

Mevdudi, Batı düşüncesinde son yüzyıllarda sıklıkla üzerinde durulan sosyal adaleti aldatıcı bir kavram olarak okumaktadır. $\mathrm{Bu}$ durumun ilk olarak on sekizinci yüzyılda bireyin özgürlüğü düşüncesiyle başladığını ve bunun neticesinde kapitalizme dayanan laik yönetimlerin oluştuğunu belirtmektedir. Dolayısıyla idari sistemlerin içerisinde yer alan, kendi şahsi durumunu ve faydasını ön plana almak isteyen herkes, bireysel özgürlükleri sıklıkla savunmuştur. Fakat ilerleyen dönemlerde Avrupa'da artan toplumsal eşitsizlikler, bu yönetimlerin sorgulanmasını da beraberinde getirmiştir. Mevdudi'ye göre Batı dünyası, toplumsal eşitsizliklere ilerleyen dönemlerde sosyal adalet aldatmacasıyla çözüm bulmaya çalışmıştır. Fakat Batı düşüncesindeki sosyal adalet, toplumsal sorunlara çözüm getiremediği gibi eşi görülmemiş küresel zulüm ve kargaşaya neden olmuştur. Dolayısıyla Batı'daki sosyal adalet anlayışı bulundukları toplumlar için bir aldatmacaya dönüşürken ilerlemenin de en son çaresi olarak görülmektedir (Mevdudi, 2006: 571-572).

Mevdudi, Batı düşüncesinde yer alan sosyal adalet kavramının eleştirisini bazı taklitçi Müslüman düşünürler üzerinden yapmaktadır. Ona göre, İslam'ın Batı kaynaklı sosyal adalet tesisine ihtiyacı yoktur. Batı düşüncesindeki sosyal adaleti İslam ile özdeşleştirenleri ise sert bir şekilde eleştirmektedir. Sosyal adalet, Mevdudi'ye göre İslam'ın bizzat kendisidir. Neyin adaletli olup olmadığı, insanlar arasında adaleti tesis etmek ise ancak Allah'a aittir. Çünkü insanların kurmuş oldukları düzen 
ilk başlarda adil olarak görünse bile uygulamalarda adalet yapılamamakta ve adil düşünülen birçok şeyin hakikatte adalet olmadığıdır. Toplumlar, kendilerine göre adil bir düzen tesis ettiklerinde bir zaman sonra bunun yeterli olmadığını ve yeni bir sosyal düzene ihtiyaç olduğu fikri belirir. Bu şekilde yeni sosyal düzenlere girişilerek istenilen sosyal adalet tesis edilmeye çalış1ır. Fakat bu sosyal düzenlerin hiçbiri, İslamiyet'in getirmiş olduğu ve tavsiye ettiği sosyal düzene yetişememiş ve insanları tam memnun edememiştir (Mevdudi, 2016: 574).

Mevdudi’nin Batı düşüncesindeki sosyal adalet eleştirisi teolojik ve felsefi noktadan İbn Rüşd'ün yaklaşımına benzemektedir. Çünkü İbn Rüşd'ün adalet teorisinde “İlâhî-beşerî adalet ayrımı gözetilirken, akı1 ile varılan beşerî adaletin kusurlu, vahiy ile bilinen ilâhî adaletin ise Allah'ın kusursuzluğunun ifadesi olduğunu belirtmektedir (Hadduri, 1999: 122-123)”. Sosyal adaleti İbn Rüşd gibi akli ve ilahi olarak iki düzeyde ele alan Mevdudi, bunların akli olanının insan aklının kusurlu ürünü, ilahi olanın ise kemalin vücud bulması olarak tarif eder. İslam'ın tesis etmiş olduğu sosyal adalet, birçok eşitsizliği giderdiği gibi ferdin hem ruh mükemmeliyetini (kemalini) hem de mutluluğunu temin etmektedir.

İslamiyet'i adaletin bizzat kendisi olarak gören Mevdudi'ye göre, bir Müslüman İslamiyet'in emirlerini bir tarafa bırakıp sosyal adaleti başka yerlerde aramamalıdır. Her nerede adaletin varlığını hissederse orada gerçekte bir İslam adaletinin varlığını görebilecektir. Dolayısıyla İslam ve adalet farklı kelimler olsa da ikisi aynı şeydir (Mevdudi, 2006: 575). İslam'da sosyal adaleti bir bütün olarak değerlendiren Mevdudi, sosyal adalette bireysel sorumluluk ve bireysel özgürlüğün esas olması gerektiğini belirtir. Bireysel sorumluluk ve özgürlük ise bireysel ve toplumsal gelişmeyi arttırmaktadır. Sosyal adalet böyle bir toplum içinde gelişmekte ve bu gelişmeyi kollayıp korumak ise hükümetlerin görevi sayılmaktadır. Hükümetlerin bu konudaki görevlerinden biri ise adil bir dağıtım ile milli gelirin halk arasında eşit bir şekilde dağıtımını sağlamaktır.

İslam' da sosyal adaletin tesis edilmesinde, bireylerin özgürlük sınırları, mülk edinmenin şartları, servetin harcanmasındaki sorumluluklar, sosyal hizmetler ve zulüm ve haksızlı̆̆ın giderilmesi Mevdudi'nin ele aldığı konulardır. Bireylerin topluma karşı belirli sorumlulukları olduğu gibi toplumunda bireylere karşı belirli sorumlulukları vardır. Birey ve toplum arasında kurulan düzende ne bireye sınırsız bir özgürlük verilir ne de topluma bireyin haklarını ihlal edecek özgürlükler verilir. Bu açıdan Mevdudi'ye göre İslam'da sosyal adalet sadece adil ve eşit ücret dağıtımı ile kısıtlı bir adalet olarak sınırlandırılmamıştır.

\subsection{Said Nursi'ye Göre Sosyal Adalet}

Batı düşünce dünyasını birçok noktadan eleştiren Nursi, eserlerinde sosyal adalet kavramına ilişkin olarak "adalet-i mahza" ve "adalet-i izafiye" gibi kavramları kullanmıştır. Adalet-i mahza, Kur'an'da emredilen ve bütün yönleriyle en küçük bir fertten bütün insanlığa kadar hak ve hukuku esas alan adalettir. Bir ferdin veya masumun hakkını hiçbir gerekçeyle iptal edilmemesini ifade eden adalet- 
i mahzada "bir masumun hakk1, bütün halk için dahi iptal edilmez. Bir fert dahi, umumun selâmeti için feda edilmez" (Nursi, 2011: 53-54). Bunun ile Nursi, sosyal hayatta tam bir adaletin tesisi ve toplum içerisinde karşılıklı hakların sağlanması, güçsüz veya masumların korunmasının esas olduğunu vurgulamaktadır. Batı düşünce merkezinde yer alan birey ve toplum, iktisadi normlara göre düzenlenirken Nursi, birey ve toplum hayatında gerçek sosyal adaletin tesisi için İslam'a uygun hareket edilmesinin gerektiğini düşünür. O'na göre sosyal adaletin tesisindeki ölçütler kişiye veya toplumlara göre değil İslam'a göre olması gerekir. Nursi, sosyal adaletin tam tesisinde Allah'ın nazarını esas alan veya İlahi olana göre bir açıklama yapar. Toplumun fayda ve hakkının bireyin önüne geçmesi, toplum için bireyin hakkının iptal edilmesini ifade eden adalet-i izafiyi (nisbi) ise; "küllün (toplumun) selâmeti için cüz'ü (kişiyi) feda eder. Cemaat (toplum) için, ferdin hakkını nazara almaz. Ehvenüşşer diye bir nevi adalet-i izafiyeyi yapmaya çalışır. Fakat adalet-i mahzâ kabil-i tatbik ise, adalet-i izafiyeye gidilmez. Gidilse zulümdür” (Nursi, 2011: 54).

Adalet-i izafiyeyi bütün olarak reddetmeyen Nursi, bu adaletin bireyin hak ve hürriyetlerinin korunmasının mümkün olmadığı sınırlı durumlarda ancak devreye girebileceğini belirtir. Modern hukukta yer alan mülk ve arazi gibi taşınmaz malların kamusal bir faaliyet veya yarar için kamulaştırması adalet-i izafiye noktasından değerlendirilebilir. Nursi (2010: 210), bu bağlamda siyasetin kendi maslahatı veya tehdit algısından dolayı bireylerin hak ve özgürlüklerinin adalet-i izafi noktasında iptal veya sınırlandırılmasının büyük haksızlık olduğunu belirtir. Çünkü İslam hukuku içerisinde yer alan özel hukuk (hukuk-u şahsi) ve amme hukukuna (hukuk-u umumiye) göre toplum içindeki bireylerin korunması esastır (Nursi, 2011: 396).

Nursi, sosyal adalet konusunda toplum içerisinde yaşayan kişinin kendi menfaatlerine hasrı nazar etmemesi gerektiği üzerinde de durur. Çünkü insanın doğası gereği medeni olarak birlikte yaşamaya mecbur olduğu ve bireylerin toplum hayatı içerisindeki münasebetlerinde birbirlerine muhtaç olduklarını belirtir. Toplum içerisinde gerçek adaletin tesisinde bireyler kendi sorumluluklarını bilmesi yanında diğer insanlarla güzel ve hakkaniyetli münasebetler içinde olması gerekir. Bunu ise bireysel planda İslami prensiplerin tahkiki bir şekilde anlaşllıp içselleştirilmesiyle mümkün görür.

Nursi, sosyal adaletin tesisinde bireyler için öncelikle ahlak ölçütünü öne çıkartmaktadır. Sosyal adaletin tesisinde Miller ve Rawls gibi bazı adalet teorisyenleri için önemli bir araç olan ahlak ölçütü, Nursi için salt ve iktisadi değildir. Çünkü Batılı adalet teorisyenleri ahlakı, belirli nesnel normlarla ortaya koymaktadır. Örneğin Rawls (2006: 159), insanlar arasında adil gelir dağılımı ve belirli nitelikteki işlerde görev almanın siyasal bir değer olduğu kadar ahlaki bir hak ediliş olduğunu vurgular. Mesela yargıçların yargı görevinde bulunmak için gerekli ehliyete sahip olmaları gerekmektedir. $\mathrm{Bu}$ gibi gözde mevkilere ulaşmak için herkesin eşit firsatlara sahip olması gerekir. Fakat bu ise Rawls için ahlaki değerden çok siyasal bir değerdir. 
Bazı İslam düşünürleri gibi Nursi ise sosyal adalette hak edilişlerin İslam'a ters olmayan kapsayıcı bir şekilde düzenlenmesi ve geliştirilmesine işaret eder. İslami bir denge içerisinde eşitliği savunarak teşebbüs-ü şahsi fikrini benimser. Buna dair Kur'an'ın teşebbüs-ü şahsiye teşvik ettiğini delil gösterir. İslam toplumlarında sosyal adaletteki ahlakın, İlahi emir ve yasaklarla bireyde gelişeceğini belirtir. Dolayısıyla Nursi, bireyin başkalarının hak ve özgürlüğüne müdahale veya hukuksuzluğunun, İslam'ın emretmiş olduğu ahlak ölçütlerine göre giderilebileceğini izah eder. Çünkü had ve cezaların İlahi emirlere göre icra edilmesi bireylerin ruh, akıl ve vicdan gibi birçok duygularını etkilemektedir. Gerçek bir adaletin sağlanmasının ise doğrudan doğruya Kur'an'ın gösterdiği yol ile gerçekleşebileceğini iddia etmektedir. Bu noktada Nursi bir ahlak ölçütü olarak adaleti, Gazzali gibi bireyde bulunan hikmet, şecaat, iffet gibi bu üç fazileti kapsayan temel bir fazilet olarak değerlendirir. Bununla birlikte adaleti, kâinatın her yerinde var olduğunu kabul ettiği nizam, mizan ve hikmet pratikleriyle insanlar arasındaki ilişkilerde de aramaktadır. Gazali'de olduğu gibi varlık dünyasındaki ölçü, aheng, denge ve hikmetlerin anlaşılmasıyla insanlar arasında gerçek adaletin anlaşılabileceğine işaret eder.

İslam ahlakının gafleti veya terki ile sosyal adalet hakikatinin kaybolacağını belirten Nursi’ye göre (2004: 390), "maslahat-1 beşeriye yerine adalet perdesi altında garazlar, zalimane ve tarafgirâne cereyanlar müdahale eder, hükümlerin tesirini kırar.” Bununla birlikte en zayıf bireyin en güçlü birey karşısında korunmasını inanç ve vicdan hürriyeti kapsamında değerlendirmektedir. Nitekim Hazreti Ömer'in kendi halifeliği zamanında bir Hıristiyan ile adilane yargılanması ve Hazreti Ali'nin bir Yahudi ile muhakeme olmasını eserlerinde örneklerken, İslam'da bireyin hiçbir zaman güçlü karşısında haksızlığa uğratılmamasını vurgular.

Sosyal eşitsizliklerin giderilmesinde sosyal yardımlaşmayı öne süren Nursi, bunun için İslami bir emir olan zekâtın yaygınlaştırılmasına işaret eder. Bununla birlikte haksız kazancın önüne geçilmesinde faizin kaldırılmasını gerekli görür. Zekâtın verilmesi ve faizin yasaklanması ile birlikte toplum içerisinde birçok eşitsizliğin önüne geçilerek adilane iktisadi bir sistem tesisi edilebilecektir. İktisadi olarak sosyal adaletin tesisini bu iki nokta üzerinden açıklayan Nursi, toplumsal huzurun sağlanması ve yoksulluğun giderilmesinde bu iki noktayı vazgeçilmez görmektedir. Dolayısıyla Nursi, Batı medeniyetinin birçok eşitsizliklerinin bu prensiplerin yokluğundan kaynaklandığını ileri sürmektedir. Bu açıdan Batı medeniyetinin bireyi fakirleştirdiğini, zengin ve yoksul tabakasını birbirinden ayırarak uzaklaştırdığını belirtir.

Nursi, Batı medeniyeti ve düşünce sistemi ile İslam medeniyeti arasında niteliksel çelişkilerin varlığına dikkat çekerek, Batı sosyal düzenin beş menfi esas üzerine kurulduğunu belirtir. O’na göre, bu düzenin dayandığı esaslar; güç, menfaat, mücadele, menfi milliyetçilik ve hevesleri tatmin etmektir. $\mathrm{Bu}$ yüzden Batı medeniyetini, sadece insanların az bir kısmına refah getiren ve diğerlerine ise mutsuzluk, tembellik ve sefahat getiren bir düzen olarak görmektedir. Fakat Nursi'nin savunduğu İslam medeniyetinin ve öngördüğü sosyal düzeninin niteliksel özellikleri ise menfi esaslar değil, müsbet 
esaslar üzerine tesis edilmiştir. Güce ve kuvvete karşıllk adalet, hedefinde menfaat ve fayda yerine fazilet ve erdem, menfi milliyetçilik yerine din ve vatan bağı, hayatta mücadele yerine sosyal yardımlaşma, heveslerin tatmini yerine İlahi emirlere göre hareketi esas alarak her iki medeniyet arasındaki niteliksel farklara dikkat çeker (Nursi, 2007: 115-120).

\section{Sonuç}

Bireyin, toplum içerisinde insan haysiyetine yaraşır asgari bir hayat standardına kavuşmasını sağlayacak ve garanti altına almaya yönelik uygulamalar bütünü olarak da tarif edilen sosyal adalet kavramı, maddi refah unsurlarının toplumun bireyleri arasında dengeli şekilde dağılımı ve adil bir yöntem izlenmesi gerektiği üzerinde durmaktadır. Sosyal adalet, Batı düşünce sistemine belirgin olarak son yüzyıllarda artan toplumsal eşitsizliklerin ve düzensizliklerin baş göstermesiyle girmiştir. $\mathrm{Bu}$ bağlamda modern Batı düşüncesi, toplumda yer alan bireyler için sosyal dengesizliklerin ve adaletsizliklerin giderilmesi üzerinde farklı yaklaşımlar ve teoriler üretmiştir. Sosyal adalet olgusunun geliştirilip toplumsal haklar çerçevesinde refahın gerçekleştirilmesi ve haksızlıkların giderilmesi üzerine yaklaşımlar iyi bir yaşam üzerine odaklanmıştır. Temel yaklaşımlarında insanı merkeze alan sosyal adalet anlayışında, değişen dünyada toplumsal düzenin getirilmesi ve ayrıcalıkların kaldırılması hedeflenmiştir. Temel hak ve hürriyetlerin korunması, ayrıcalıkların kaldırılması, eşit muamelenin yapılması, adaletin yerli yerinde dağıtımı, temel ihtiyaçların temini sosyal adalet anlayışı üzerinden değerlendirilmiştir. İslam düşüncesinde de bu temel yaklaşımlar insanın farklılı̆̆ı, inancı, kimliği, ırkı, statüsü sosyal adalet anlayışı çerçevesinde değerlendirilirken sosyal adaletin hakkaniyet ölçüsünde tesis edilmesi üzerinde durulur. Genel anlamda sosyal adaletin tesisinden doğacak toplumsal faydaya da dikkat çeker. Yalnız modern Batı düşünce sisteminden farklı olarak İslam düşüncesi, sosyal adaletin bütün değer ve normlarla ilişkili olarak ilahi bir kaynaktan beslendiği üzerinde durmakta ve bu ilahi değeri bir ahlak ölçütü üzerinden açıklamaktadır. İnsanların kurmuş oldukları salt dünyevi düzen ve adaletin kapsayıcı olmadığını ve Batı düşüncesinde sosyal adaletin standartları belirli bir toplumda tedavülde olan anlayış ve beklentilerle ilişkili olmasından dolayı eleştirmektedir. $\mathrm{Bu}$ iki farklı düşüncenin ortak noktalarından en önemlisi ise insanın onurlu, adilane ve hür bir hayat sürmesi için adil bir toplumun tesis edilmesidir. Fakat modern Batı düşüncesinde sosyal adalet, güzel bir yaşam için iken İslam düşüncesinde doğru, erdemli ve ahlaki (faziletli) bir toplum için gereklidir. Çünkü İslam'ın öngördüğü bir toplumda sosyal adaletin tesisi ile sadakat, vefa, şefkat, sıla-i rahim, teslim, tevekkül, ibadet, mükâfat ve ortak işlerde dürüst hareket etmek bir çeşit adaletin faziletleri olarak yansıyacaktır.

Bat1 düşüncesinde sosyal adalet belirli evrelerden sonra gelişme gösterirken, İslam düşüncesinde ise başlangıçtan beri var olan tabii haklar görülmüştür. Dolayısıyla İslam toplumlarında, temel hak ve hürriyetler gibi birçok sosyal hak, Batı'da ki gibi farklı safhalardan geçmemiştir. Miller ve Rawls gibi liberal Batı düşünürleri, sosyal adaleti herkes için geçerli bir özgürlük düzeniyle bağdaştırmakta ve temel özgürlüklerin kapsamlı bir sistem içerisinde olması gerektiğini vurgulamaktadır. Fakat “Kant’tan Rawls'a liberal adalet teorileri, teolojik yaklaşımların temel 
özgürlüklere ilişkin değerlendirmelerine mesafeli durmaktadır. Çünkü Kant gibi Rawls’a göre iyi yaşam düşüncesine dayanan dinsel adalet teorileri özgürlükle bağdaşmayacağı gibi kendi amacını ve hedefini seçen özgür birey anlayışıyla da örtüşmez. Bireylerin kendi amaçlarını seçmekte özgür olması gerektiği düşüncesinin bizatihi ahlaki bir düşünce olduğunu savunur" (Sandel, 2015: 276-297). Buna göre iyi bir hayat tesisinde sosyal adalet, üstün ahlaki bağlara sahip olmayan özgür olarak tercih yapabilen birey düşüncesini yansitır.

Bu anlamda Batı düşünürleri için sosyal adalet genel olarak özgür bir yaşam ve iktisadi ölçütler etrafında değerlendirilmektedir. Sosyal adaletin tesisinde ahlak ilkesi bile siyasal ve maddi ölçütler çerçevesinde değerlendirilirken İslam'da ahlak ölçütü tevhid ile şekillenmektedir. Çağdaş İslam düşünürlerinden olan Kutub, Mevdudi ve Nursi ise sosyal adaletin salt ve dünyevi yani maddi ölçütler ile sağlanamayacağını belirtmektedirler. Bu düşünürler göre sosyal adaletin uygulanabilirliği için tevhid düşüncesinin bir toplumda hâkim olması gerekmektedir. Dolayısıyla bir toplumda gerçek ve mükemmel sosyal adaletin tesisi ancak İslam'ın emretmiş olduğu prensiplerle var olabilecektir. Bunun önceliğinde ise bireyin akıl, ruh ve vicdanını İslam ahlakına göre şekillendirmesi gerekir. Dolayısıyla İslam'a göre insanın duygularıyla ilişkili bir fazilet olan adalet hakikati, başlangıçta bireyin (kulun) terbiyesi, ortada sosyal adaletin tesisi sonunda ise ahiretin tezahürü iledir. 


\section{Kaynakça}

AKGÜNDÜZ, Ahmed (1997), İslam'da Insan Hakları Beyannamesi, Osmanlı Araştırmalar Vakfı Yayınları, İstanbul.

BERKES, Niyazi (2008), Türkiye'de Çağdaşlaşma, Yapı Kredi Yayınları, İstanbul.

BİLGiN, Mehmet Fevzi (1996), “John Rawls’un Adalet Kuramı ve İslam Hukuku Işı̆̆ında Değerlendirilmesi”, Divan: Disiplinlerarası Çalışmalar Dergisi, Cilt 1, Sayı: 2, ss. 207-215.

CAMPBELL, Tom D. (2008), “Adalet”, Modern Toplumsal Düşünce Sözlüğü, (Ed.) William Outhwaite, (Haz.) Melih Pekdemir, İletişim Yayınları, İstanbul, ss. 20-21.

ÇAĞIRCI, Mustafa (1988), “Adalet”, TDV İslam Ansiklopedisi, TDV Yayınları, Cilt 1, İstanbul, ss. 341-343.

FLEISCHACKER, Samuel (2013), Dağıtıcı Adaletin Kısa Tarihi, (Çev.) Gökhan Murteza ve Eylem Yolsal Murteza, Pinhan Yayınc1lik, İstanbul.

GÖZE, Ayferi (2013), Siyasal Düşünceler ve Yönetimler, Beta Yayınları, İstanbul.

HADDURİ, Macid (1999), İslam'da Adalet Kavramı, (Çev.) Selahattin Ayaz, Yöneliş Yayınları, İstanbul.

HAMIDULLAH, Muhammed (1965), İslam'a Giriş, (Çev.) Mehmet Yazgan, Nur Yayınları, Anakara.

HARVEY, David (2013), Sosyal Adalet ve Şehir, (Çev.) Mehmet Moralı, Metis Yayınları, İstanbul.

HÜNLER, Solmaz Zelyüt (1997), Rawls ve Macıntyre - İki Adalet Arasinda Liberal ve Komunitaryan Düşüncenin Çatışma Alanı, Vadi Yayınları, Anakara.

KARAMAN Hayreddin (1988), “Adalet”, TDV İslam Ansiklopedisi, TDV Yayınlar1, Cilt 1, İstanbul, ss. 343-344.

KUTUB, Seyyid (2014), İslam'da Sosyal Adalet, (Çev.) Harun Ünal, Beka Yayınları, İstanbul.

MEVDUDİ, Ebu'l A'la (2006), İslam'da Hükümet, (Çev.) Ali Genceli, Hilal Yayınları, İstanbul.

MILLER, David (1994), “Adalet”, Blackwell’in Siyasal Düşünce Ansiklopedisi I, (Haz.) David Miller vd., (Çev.) Bülent Peker ve Nevzat Kıraç, Ümit Yayıncılık, Anakara, ss. 14-19.

MILLER, David (1999), "Social Justice and Environmental Goods", Fairness and Futurity: Essays on Environmental Sustainabilitiy and Social Justice, (Ed.) Andrew Dobson, Published of Oxford, ss. 151-172.

MILLER, David (2003), Principles of Social Justice, Harvard University Press, London.

MILLER, David (2008), "Eşitlik ve Eşitsizlik”, Modern Toplumsal Düşünce Sözlüğü, (Ed.) William Outhwaite, (Haz.) Melih Pekdemir, İletişim Yayınları, İstanbul, ss. 237-240.

NURSİ, Said (2007), Lem 'alar, Envar Neşriyat, İstanbul.

NURSİ, Said (2010), Emirdağ Lahikası I, Envar Neşriyat, İstanbul.

NURSİ, Said (2011), Mektubat, Envar Neşriyat, İstanbul.

ÖZCAN, Azmi (2001), “Günümüz İslâm Dünyası Fikir Hareketleri”, TDV İslam Ansiklopedisi, TDV Yayınlar1, Cilt 23, İstanbul, ss. 37-42.

ÖZTÜRK, Armağan (2014), "Kant Liberalizmi Arka Planında ve Sosyal Adalet Sorunsalı Özelinde Rawls'un Adalet Teorisinin İdeolojik Sınırları", Sosyal Adalet İçin İnsan Hakları: Sosyal Haklar, (Ed.) Kıvılcım Akkoyunlu Ertan vd., TODAİE Yayını, Ankara, ss. 19-32.

PEFFER, R. G. (2001), Marksizm, Ahlak ve Toplumsal Adalet, (Çev.) Yavuz Alogan, Ayrıntı Yayınları, İstanbul.

RAWLS, John (2006), Hakların Yasası ve Kamusal Akıl Düşüncesinin Yeniden Ele Alınması, (Çev.) Gül Evrin, İstanbul Bilgi Üniversitesi Yayınları, İstanbul.

SAID, Edward W. (2003), Şarkiyatçıllk, (Çev.) Berna Ünler, Metis Yayınları, İstanbul.

SAID, Edward W. (2007), Medyada İslam, (Çev.) Aysun Babacan, Metis Yayınları, İstanbul.

SANDEL, Michael J. (2015), Adalet: Yapılması Gereken Doğru Şey Nedir, (Çev.) Mehmet Kocaoğlu, BigBang Yayınları, Ankara.

SUNAL, Onur (2011), "Sosyal Politika: Sosyal Adalet Açısından Kavramsal Bir Değerlendirme", Ankara Üniversitesi SBF Dergisi, Cilt: 66, No: 3, ss. 283-305.

TOPALOĞLU, Bekir (1988), “Adl”, TDV İslam Ansiklopedisi, TDV Yayınları, Cilt 1, İstanbul, s. 387. 
TYLER, Tom R. (2003), “Social Justice”, Blackwell Handbook of Social Psychology: Intergroup Processes, (Ed.) Rupert Brown and Samuel L. Gaertner, Blackwell Puplishing, Berlin, ss. 344-364.

UDEH, Abdulkadir (1968), “İslam'da Fertlerin Hukuku”, İslam Medeniyeti, (Çev.) Mahmud Özakkaş, Y11: 2, Sayı: 14, ss. 21-24.

YAYLA, Atilla (2000), Özgürlük Yolu Hayek'in Sosyal Teorisi, Liberte Yayınları, Anakara. 